\title{
Faktor Yang Mempengaruhi Tingkat Kesadarana Masyarakat Pesisir Terhadap Pengelolaan Sampah di Perairan Teluk Ambon Kota Ambon
}

\author{
Marthinus J. Saptenno ${ }^{1}$, Lidya B.E. Saptenno ${ }^{2}$, Natelda R. Timisela ${ }^{3 *}$
}

${ }^{1}$ Fakultas Hukum Universitas Pattimura, Indonesia

2Fakultas Kedokteran Universitas Pattimura, Indonesia

${ }^{3}$ Fakultas Pertanian Universitas Pattimura, Indonesia

\begin{abstract}
ABSTRAK
Penelitian bertujuan menganalisis faktor yang mempengaruhi tingkat kesadaran masyarakat pesisir terhadap pengelolaan sampah di perairan Teluk Ambon Kota Ambon. Penentuan sampel dilakukan secara simple random sampling dengan jumlah responden sebesar 148 orang. Analisis Data penelitian dilakukan secara kualitatif dan kuantitatif. Analisis secara kualitatif untuk menjelaskan kesadaran masyarakat terhadap sampah di daerah pesisir sedangkan analisis data secara kuantitatif dilakukan untuk menganalisis faktor yang mempengaruhi kesadaran masyarakat terhadap pengelolaan sampah menggunakan analisis SEM-PLS. Hasil penelitian menunjukkan bahwa kepadatan sampah domestik terutama sampah plastik di Teluk Ambon bagian dalam mengalami peningkatan dalam 20 tahun terkahir. Kesadaran masyarakat yang dilihat dari aspek pengetahuan, sikap dan perilaku menunjukkan bahwa pengetahuan masyarakat rendah terhadap kesadaran dalam pengelolaan sampah. Sikap dan perilaku masyarakat dalam pengelolaan sampah baik, namun masih harus ditingkatkan terus kesadaran tentang pentingnya pengelolaan sampah bagi masyarakat pesisir. Model struktural berdasarkan nilai t-value, menunjukkan bahwa konstruk pengetahuan tidak memberikan pengaruh yang signifikan terhadap konstruk perilaku, karena nilai $t$-nya $(\mathrm{t}$ Pengetahuan -> Perilaku =0,472 lebih kecil dari nilai yang disarankan ( $\mathrm{t}$-value $<1,96$ ). Pada konstruk perilaku memberikan pengaruh yang signifikan terhadap konstruk kesadaran, nilai t-nya $>1,96$ ( $\mathrm{t}$ perilaku $\rightarrow$ kesadaran=3,647). Sementara itu, konstruk sikap memberikan pengaruh yang signifikan terhadap konstruk perilaku, nilai $t$-nya (t sikap $\rightarrow$ perilaku $=6,290$ ) lebih besar dari nilai $t$ yang disarankan $(t>1,96)$. Nilai $R$-Square, diperoleh nilai untuk konstruk kesadaran dan perilaku masingmasing sebesar 0,235 dan 0,686. Hal ini dapat dijelaskan bahwa untuk setiap peningkatan sikap dapat memberikan pengaruh terhadap kesadaran dan perilaku masing-masing sebesar $23,5 \%$ dan $68,6 \%$. Sedangkan sisanya yaitu masing-masing sebesar 76,5\% dan 31,4\% dipengaruhi oleh faktor lain di luar model.
\end{abstract}

Kata kunci: Kesaadran, sampah, pengelolaan, SEM-PLS, Kota Ambon.

\begin{abstract}
This study aims to analyze the factors that influence the level of awareness of coastal communities towards waste management in the waters of Ambon Bay, Ambon City. Determination of the sample is done by simple random sampling with the number of respondents amounted to 148 people. Analysis of research data was carried out qualitatively and quantitatively. Qualitative analysis is to explain public awareness of waste in coastal areas, while quantitative data analysis is carried out to analyze factors that influence public awareness of waste management using SEM-PLS analysis. The results showed that the density of domestic waste, especially plastic waste in the inner Ambon Bay, has increased in the last 20 years. Public awareness seen from the aspect of knowledge, attitude and behavior shows that public knowledge is low on awareness in waste management. The attitude and behavior of the community in waste management is good, but awareness must continue to be increased about the importance of waste management for coastal communities. The structural model based on the $t$-value shows that the knowledge construct does not have a significant effect on the behavioral construct, because its $t$-value $(t$ Knowledge $->$ Behavior $=0.472$ is smaller than the recommended value ( $t$-value $<1.96)$. The behavioral construct has a significant effect on the construct of consciousness, the tvalue is $>1.96$ ( $t$ behavior $\diamond$ awareness=3.647). Meanwhile, the attitude construct has a significant influence on the behavioral construct, the $t$-value ( $t$ attitude $\diamond$ behavior $)=6.290$ ) which is greater than the recommended $t$ value $(t>1.96)$. The value of $R$ Square, obtained values for the constructs of consciousness and behavior of 0.235 and 0.686 , respectively. This can be explained that for each increase in attitude can have an effect on awareness and behavior are $23.5 \%$ and $68.6 \%$, respectively, while the remaining $76.5 \%$ and $31.4 \%$ are influenced by other factors outside the model, respectively.
\end{abstract}

Keywords: Awareness, waste, management, SEM-PLS, Ambon City.

Citation: Saptenno, M.J., Saptenno, L. B.E., Timisela, N.R. (2022). Faktor Yang Mempengaruhi Tingkat Kesadaran Masyarakat Pesisir Terhadap Pengelolaan Sampah di Perairan Teluk Ambon Kota Ambon. Jurnal Ilmu Lingkungan, 20(2), 365-374, doi:10.14710/jil.20.2.365-374

\footnotetext{
* Penulis korespondensi: nateldatimisela@gmail.com
} 


\section{Pendahuluan}

Lingkungan sebagai tempat hidup semua makhluk. Sebagai salah satu faktor terbesar yang mempengaruhi derajat kesehatan adalah lingkungan, oleh sebab itu menjaga lingkungan merupakan tanggung jawab semua orang (Hendrik L. Blum, 1974 dalam Slamet, 2016). Peran masyarakat untuk menjaga lingkungan penting karena masyarakat harus menyelesaikan masalah lingkungan hidup. Setiap hari kehidupan masyarakat selalu dipenuhi dengan banyak kebutuhan, oleh sebab itu lingkungan hidup sebagai kebutuhan penting harus dijaga dan dilestarikan. Permasalahan lingkungan yang terbesar adalah kebersihan. Agar kesehatan tetap terjaga, maka kebersihan lingkungan juga perlu dijaga. Lingkungan bersih berarti terbebas dari berbagai kotoran yang merugikan semua aspek kehidupan. Sangat diperlukan kesadaran masyarakat untuk menjaga kebersihan lingkungan. Sesuatu yang berkaitan dengan kebersihan yaitu mengelola sampah secara baik.

Aktivitas hidup setiap hari, masyarakat selalu berhadap dengan sampah. Semua yang beraktivitas pasti akan menghasilkan sampah. Banyak penelitian dilakukan terkait sampah, hasilnya pengelolaan sampah kurang baik dikarenakan sempitnya lahan atau lahan tidak tersedia untuk membangun tempat sampah sementara, failitas sarana dan prasarana kurang menunjang, rendahnya tingkat kesadaran masyarakat untuk mengelola sampah (Elamin et al, 2018). Benda atau bahan yang sudah tidak berguna dan dibuang merupakan sampah. Masyarakat memandang sampah sebagai hal yang kotor, jijik dan lainnya. Oleh sebab itu diperlukan pembakaran atau pembuangan sampah (Mulasari, 2012). Pengolahan sampah supaya tidak menimbulkan dampak negatif bagi lingkungan merupakan tanggung jawab semua orang termasuk pemerintah daerah (Hardiatmi, 2011).

Perhatian dunia terhadap sampah menjadi prioritas. Di Kota Ambon terutama pada instalasi Pembuangan Sampah Terpadu (ITPS) di Toisapu tercatat 162,5ton sampah per hari yang ditimbun. Jumlah sampah di ITPS yang sangat tinggi, masyarakat dituntut untuk serius memikirkan masalah sampah. Pemerintah telah menyiapkan dan menyalurkan beberapa peralatan seperti truk, tossa dan gerobakgerobak yang dapat diakses oleh masyarakat desa terpencil. Oleh sebab itu perlu meningkatkan kesadaran masyarakat melalui kegiatan sosialisasi untuk menumbuhkan kesadaran generasi muda akan pentingnya sampah (Sohilait, 2019).

Sampah yang ada di Kota Ambon hampir tersebar di atas permukaan laut, pesisir pantai dan memenuhi dasar laut. Terdapat tiga macam ekosistem (palung, mangrove, dan terumbu karang) dan biota laut yang langka (hewan mikroskopik tak kasat mata) di Teluk Ambon terancam punah. Padahal hewan-hewan ini dicari wisatawan asing sebagai bahan untuk pemotretan (Toisuta dan Salampessy, 2019).

Hidup sehat, nyaman dan bersih sangat tergantung pada lingkungan yang bersih dan sehat.
Masyarakat yang tidak peduli sampah, maka akan muncul masalah lingkungan antara lain kesehatan terganggu, terjadi banjir, air tercemar, udara tercemar dan lainnya. Jika lingkungan hidup bersih akan tercipta rasa nyaman, aman dan sehat. Sebaliknya lingkungan kotor maka kehidupan tidak nyaman, aman dan terganggun. Lingkungan kotor menimbulkan berbagai penyakit. Sampah dan genangan air pada saluran yang tidak lancar menyebabkan munculnya nyamuk demam berdarah yang akan berkembang biak dengan baik sehingga banyak masyarakat akan terkena penyakit demam berdarah. Berdasarkan uraian di atas maka tujuan penelitian untuk menganalisis faktor yang berpengaruh terhadap tingkat kesadaran masyarakat pesisir terhadap pengelolaan sampah di perairan Teluk Ambon Kota Ambon.

\section{Metode Penelitian}

Penelitian berlangsung pada bulan AgustusOktober 2021 berlokasi di desa Rumahtiga, Galala, Passo, Lateri, Halong, Hative Kecil dan Hative Besar. Penentuan lokasi dilakukan secara purposive sampling dengan alasan bahwa masyarakat ketujuh desa berada di pesisir Kota Ambon. Sampel ditentukan secara simple random sampling. Jumlah responden sebesar 148 orang yang tersebar pada ketujuh lokasi tersebut. Data penelitian dianalisis secara kualitatif dan kuantitatif. Data yang dianalisis secara kualitatif untuk menjelaskan kesadaran masyarakat terhadap sampah di daerah pesisir, sedangkan data yang dianalisis secara kuantitatif terhadap faktor-faktor yang mempengaruhi kesadaran masyarakat terhadap pengelolaan sampah menggunakan analisis SEM-PLS. Penentuan respons sampel menggunakan skala likert 1-5 (tidak baik, kurang baik, cukup, baik, sangat baik). Pengetahuan (P) terdiri dari P1: mengetahui; P2: memahami; P3: mengaplikasi. Sikap (S) terdiri dari S1: kepercayaan; S2: kehidupan emosional/evaluasi terhadap suatu objek; S3: Kecenderungan untuk bertindak. Perilaku (PL) terdiri dari PL1: kebiasaan; PL2: keyakinan; PL3: prinsip. Kesadaran terdiri dari KS1: refleks nurani; KS2: cara pandang dan KS3: ulet dan Tangguh. Analisis data menggunakan SEM-PLS.

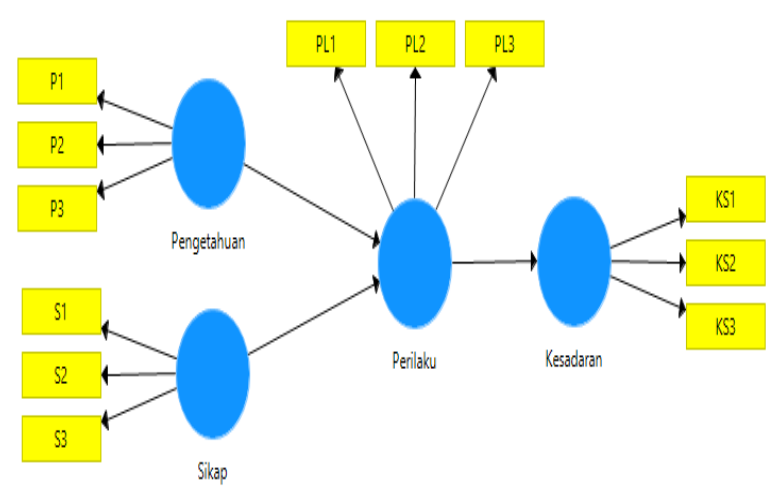

Gambar 1. Kerangka Analisis Pengaruh Pengetahuan, Sikap dan Perilaku Terhadap Kesadaran Masyarakat 


\section{Hasil dan Pembahasan}

\subsection{Kepadatan Sampah Plastik di Teluk Ambon}

Kepadatan sampah domestik khusus sampah plastik di Teluk Ambon bagian dalam menurut Lembaga ilmu pengetahuan Indonesia (P2LD-LIPI) meningkat dalam 20 tahun belakangan. Jumlah sampah yang melimpah terjadi pada delapan titik lokasi pantai mulai dari Desa Poka $(47,42$ persen), Desa Hative $(17,04$ persen), Kate-Kate (11,73 persen), Waiheru $(9,28$ persen), Tawiri (6,9 persen), Lateri (4,34 persen), Halong (2,49 persen), dan Desa Passo (0,78 persen). Terjadi ledakan alga berbahaya di Teluk Ambon sebagai akibat peningkatan kepadatan sampah dan limbah. Dinamika ledakan alga jenis pydrodinium mencapai 10.000.000 sel per liter. Tahun 2019 dan 2020 di Teluk Ambon terjadi ledakan 'Non-toxic alga gonyaulax spp. Terjadinya ledakan alga disebabkan sampah yang menumpuk di laut. Di Kota Ambon, terdapat sungai besar dan sungai kecil sebanyak 29 sungai yang bermuara langsung ke Teluk Ambon bagian dalam. Jumlah sungai yang berada di pemukiman padat penduduk sebanyak 19 sungai, sangat berdampak karena sungai-sungai ini membawa minyak, sedimentasi, dan sampah termasuk limbah rumah tangga langsung ke laut (Andi, 2021).

Masalah serius bagi pemerintah Provinsi Maluku yaitu terdapatnya sampah yang menumpuk di laut. Hasil kajian LIPI pada tahun 2017 menunjukkan bahwa kepadatan sampah domestik terutama sampah plastik sangat meningkat di Teluk Ambon bagian dalam. Terdapat 51 jenis sampah, terutama di wilayah dekat pasar Mardika dan Galala. Dinas Lingkungan Hidup dan Persampahan Kota Ambon harus bersama-sama masyarakat melakukan kegiatan pembersihan sampah di perairan teluk Ambon. Aktivitas ini sudah menjadi kegiatan rutin yang dilakukan untuk menjaga kebersihan dan keindahan Teluk Ambon. Penggunaan speedboat untuk mengangkat sampah di permukaan laut terus dilakukan supaya menjaga laut tetap bersih dan indah.

\subsection{Tinjauan Pengetahuan, Sikap, Perilaku dan Kesadaran Masyarakat Terhadap Pengelolaan Sampah}

\subsubsection{Pengetahuan}

Pengetahuan sebagai sebuah proses untuk mengetahui sesuatu oleh seseorang setelah melakukan penginderaan untuk objek tertentu. Penginderaan terjadi seperti melihat, mendengar, mencium, merasa dan meraba. Pengetahuan manusian akan terjadi melalui mata dan telinga (Notoatmodjo, 2007).

Pengetahuan penting untuk pembentukan tindakan dan karakter seseorang. Berkaitan dengan pengelolaan sampah, maka akan menunjukkan intlektual orang yang akan tanggap terhadap sampah. Pengetahuan responden terkait sampah dibentuk oleh kemampuan berpikir sesuai kenyataan yang diperoleh dari lingkungan sekitarnya. Prinsip-prinsip pengelolaan sampah meliputi waktu membuang sampah, perilaku membuang sampah pada tempatnya, frekuensi membuang sampah per hari, memilah sampah organic dan non organik, sampah tidak dibakar, melakukan aktivitas bersama untuk mengatasi masalah sampah.

Tabel 1 memperlihatkan sebanyak 57,43\% responden mempunyai pengetahuan baik untuk pengelolaan sampah sedangkan $42,57 \%$ responden memiliki pengetahuan kurang baik untuk mengelola sampah. Proses ini disebabkan kebanyakan responden masih membuang sampah di tepi pantai bahkan ke laut. Terdapat masyarakat yang belum taat dalam mengelola sampah. Pengetahuan dipengaruhi oleh tingkat pendidikan, infomasi, budaya dan pengalaman. Hasil penelitian Marojahan, 2015 menyatakan bahwa pengetahuan masyarakat dipengaruhi oleh tingkat Pendidikan, informasi dan budaya. Tingkat Pendidikan menjadi utama, karena seseorang dengan tingkatan Pendidikan tinggi akan lebih mengerti tentang pengelolaan sampah. Hasil penelitian memperlihatkan terdapat $65 \%$ tingkat Pendidikan responden rata-rata berada pada kategori SMA-Perguruan tinggi. Ini berarti bahwa mereka akan lebih mengetahui cara penanganan sampah. Namun $35 \%$ berada pada kategori tingkatan Pendidikan rendah sehingga merasa masa bodoh dengan hal sampah. Selain itu, terkait informasi kebanyakan masyarakat pada ketujuh lokasi penelitian di Kota Ambon belum mengikuti penyuluhan untuk pengelolaan sampah. Oleh sebab itu, sangat berdampak pada minimnya pengetahuan masyarakat tentang sampah. Selain itu masyarakat tidak mengetahui cara dan metode mengelola sampah. Pengetahuan masyarakat tentang sampah dipengaruhi juga oleh budaya, masyarakat menganggap membuang sampah ke tepi pantai atau ke laut menjadi kebiasaan, lebih mudah, tidak perlu berjalan mencari tempat sampah dan dekat dengan rumah. Ini menjadi sebuah budaya yang terus dipupuk karena tidak mau berpikir dampaknya. Pengalaman seseorang dalam mengelola sampah sangat tergantung pada pengetahuannya. Jika pemahamannya baik tentang sampah maka pengetahuan untuk pengelolaan sampah akan lebih baik. Seseorang dengan segudang pengalaman pastinya lebih mengerti dan memahami tentang sampah yang berkaitan dengan cara-cara pengelolaannya.

\subsubsection{Sikap}

Sikap setiap orang akan berbeda-beda terhadap sebuah objek. Sikap bertalian dengan penilaian, perasahaan dan tindakan. Perbedaan sikap disebabkan pengalaman, pertimbangan, dan pemahaman yang dialami seseorang. Sikap berhubungan dengan tindakan positif maupun negatif tentang objek psikologi. Seseorang bersikap positif untuk sebuah objek psikologi jika orang itu mempunyai sikap favorable. Begitu juga orang bersikap negatif terhadap objek psikologi jika orang tersebut sikapnya unfavorable (Ahmadi, 2009). Berkaitan dengan sikap 
masyarakat untuk mengelola sampah sangat tergantung pada kesiapan antisipatif untuk menyelesaikan masalah sampah. Menurut Azwar, 2015, sikap merupakan kondisi stimuli sosial dari sebuah respons yang terjadi.

Tabel 1 menunjukkan bahwa 55,41\% responden menunjukkan sikap yang baik untuk mengelola sampah dan 44,59\% responden menunjukkan sikap kurang baik. Hal ini mengindikasikan bahwa sampah menjadi penting karena berkaitan dengan sikap seseorang untuk peduli terhadap sampah. Sampah harus dibuat pada tempatnya dan bukan dibuang ke tepi pantai atau ke laut. Karena sikap masa bodoh maka, masyarakat tidak mau tahu dengan keadaan, apa saja mereka lakukan yang penting sampah tidak ada di depan mata mereka. Sebanyak 65 \% responden di ketujuh lokasi penelitian terkadang belum meunjukkan sikap yang baik dalam pengelolaan sampah. Mereka belum dapat memilih sampah menurut jenisnya. Semua sampah masih dibuang seenaknya tanpa peduli lingkungan. Namun sebanyak 35\% dapat memilah sampah menurut jenisnya. Hasil penelitian Banga (2011) menunjukkan bahwa masyarakat mempunyai bersikap positif dan sadar untuk memiliah sampah dan melakukan daur ulang merupakan langkah yang baik supaya sampah tidak menumpuk pada suatu tempat. Terlihat masyarakat di di Teluk Ambon mempunyai partisipasi yang rendah untuk memilah sampah. Oleh sebab itu jika disosialisasikan dan diberikan penyuluhan yang kontinu terkait pengelolaan sampah kepada masyarakat teluk Ambon maka akan sangat bermanfaat bagi masyarakat dalam peningkatan keuntungan baik moril maupun material. Pemerintah harus berperan aktif untuk menata proses pemilahan sampah dan mengkampanyekan konsekuensi atas pengelolaan sampah yang salah dan keuntungan memilah sampah. Hal ini didukung oleh hasil penelitian lain yaitu penekanan pada kegiatan daur ulang sebagai strategi pengelolaan sampah berkelanjutan telah mewakili pergeseran paradigma dari praktik pengumpulan dan pembuangan sampah konvensional. Studi terbaru merekomendasikan penggunaan kembali dan daur ulang limbah padat (Banga, 2008; Ekere et al., 2009; Omran et. al., 2009; Pokhrel dan Viraqraghavan, 2005). Namun, untuk setiap kegiatan daur ulang berlangsung, limbah harus dipisahkan. Salah satu permasalahan dalam pengelolaan sampah adalah belum adanya budaya memilah sampah berdasarkan jenisnya di titiktitik timbulan. Hal ini mengakibatkan tercampurnya semua jenis sampah.

\subsubsection{Perilaku}

Kegiatan atau aktivitas manusia yang diamati secara langsung maupun tidak oleh pihak luar merupakan konsep perilaku (Notoatmodjo, 2007). Penanganan sampah sangat berkaitan dengan perilaku seseorang. Manusia yang tidak tanggap terhadap sampah akan menimbulkan masalah kerusakan lingkungan. Manusia yang hanya mementingkan kepentingan pribadi daripada kepentingan umum akan menyebabkan daya dukung lingkungan akan terkuras sehingga mengakibatkan kerusakan lingkungan yang semakin tinggi.

Tabel 1 menunjukkan bahwa $60,81 \%$ responden menunjukkan perilaku baik terhadap pengelolaan sampah sedangkan 39,19\% menunjukkan perilaku yang kurang baik. Ini artinya bahwa jika orang bertanggung jawab terhadap sampahnya maka mereka peduli terhadap lingkungan sekitarnya. Namun jika tidak peduli maka seenaknya saja mereka melakukan aktivitas apapun yang menghasilkan sampah dan tidak mau mengelolaan sampah secara baik. Perilaku orang terhadap sampah beranekaragam. Ada yang mengetahui dampak negatif ketika sampah dibiarkan. Penelitian memperlihatkan bahwa $62,2 \%$ responden mengemukakan bahwa pengaruh atau dampak negatif sampah yaitu membuat lingkungan sekitar menjadi kotor, membuat lingkungan menjadi tidak indah, membuat terumbu karang rusak, membuat biota laut dan makhluk lainnya menjadi tidak berkembang dan mati serta tidak dapat melindungi mangrove. Sedangkan 37,8\% menyatakan bahwa sampah dibiarkan karena tidak ada tempat yang representatif untuk penampungan. Perilaku orang yang membuang sampah ke laut karena beberapa alasan. Hasil penelitian menunjukkan bahwa sebanyak 67,3\% menyatakan bahwa alasan mereka membuang sampah ke tepi pantai/sekitar pesisir/ke laut karena tidak tersedia tempat sampah representative. Sedangkan 16,8\% menyatakan bahwa menjadi kebiasaan dari dulu yang selalu membuang sampah ke tepi pantai/sekitar pesisir/ke laut. Selain itu 15,8\% mengatakan bahwa lebih mudah atau gampang membuang ke tepi pantai/sekitar pesisir/ke laut. Sedangkan ada tanggapan responden yang tidak membuang sampah ke tepi pantai atau di sekitar pesisir dan laut sebanyak 64,8\% untuk menjaga kelenstarian dan kberhasilan lingkungan laut, sebanyak 18,4\% merespons bahwa untuk merawat lingkungan laut dan unsur-unsur di dalamnya, sebanyak 16\% menjawab bahwa untuk mencegah kerusakan lingkungan dan 0,8\% menjawab bahwa untuk menjaga hutan bakau tetap subur. Kesadaran masyarakat untuk menjaga laut masih rendah karena belum $80 \%$ menjaga pantai secara berkelanjutan.

\subsubsection{Kesadaran Masyarakat terhadap Pengelolaan Sampah}

Kondisi saat ini tidak dipungkiri karena banyak orang berperilaku tidak baik terkait sampah. Orang membuang sampah tidak di tempat sampah. Apalagi masyarakat di sekitaran Teluk Ambon yang belum dapat dikendalikan dalam pengelolaan sampah. Kebanyakan orang masih membuang sampah sembarangan. Namun ada juga orang yang sudah sadar sampah sehingga tidak membuang sampah seenaknya. Masyarakat yang belum sadar untuk membuang sampah secara teratur pada tempat sampah, sebanyak 45\%. Terlihat bahwa perilaku masyarakat untuk 
membuang sampah secara sembarangan tidak pandang tingkatan pendidikan dan status sosial. Keberadaan sampah setiap hari dalam kehidupan semua orang tidak terlepas dari ulah manusia yang membuang sampah secara bebas dan sembarangan, setiap orang menganggap bahwa barang yang tidak layak pakai tidak berguna sehingga mereka membuang dengan seenaknya saja.

Masyarakat tidak sadar akan pentingnya kebersihan merupakan faktor dominan disamping kepekaan terhadap lingkungan. Mereka belum mengetahui bahaya yang akan terjadi jika lingkungan diabaikan (Nurdin, 2004). Sampah domestik membutuhkan perhatian ekstra dari seluruh kelompok masyarakat dalam menangani sampah. Pemerintah harus menjadi fasilitator dan motivator untuk terus menyuarakan penanganan sampah agar tercipta lingkungan bersih, asri dan sehat. Ketidakpedulian masyarakat terhadap sampah maka akan menimbulkan degradasi kualitas lingkungan yang berdampak pada kualitas hidup masyarakat di suatu wilayah. Teknik pengelolaan berwawasan lingkungan akan menimbulkan kualitas perwujudan pengelolaan sampah yang sesuai (Marojahan, 2015). Perilaku dalam mengelola sampah dengan baik akan tercapai jika pengetahuan masyarakat tentang penanganan sampah semakin bertambah dan meningkatkan kesadaran masyarakat untuk tanggap terhadap sampah di lingkungan sekitar. Jumlah penduduk semakin bertambah maka akan berdampak pada produksi sampah yang semakin meningkat. Namun, apabila masyarakat menunjukkan perilaku yang baik dalam mengelola sampah maka akan menghasilkan lingkungan yang sehat, aman, bersih dan nyaman bagi kehidupan setiap orang (Marojahan, 2015).

Upaya meningkatan kesadaran masyarakat yaitu terus memberikan edukasi tentang sampah dan dampaknya melalui tingkatan pendidikan baik formal maupun non formal. Peningkatan kesadaran masyarakat melalui pendidikan formal dibangun dari tingkat Pendidikan anak usia dini, taman kanak-kanak, sekolah dasar, sekolah menengah pertama, sekolah menengah atas dan perguruan tinggi. Hal ini mutlak dilakukan supaya kesadaran anak-anak muda terhadap sampah lebih ditingkatkan lagi. Memberikan edukasiedukasi penting tentang penanganan sampah yang baik dan benar. Sedangkan Pendidikan non formal diperuntukan bagi masyarakat yang tinggal di pesisir pantai dengan memberikan penyuluhan dan sosialisasi tentang dampak negative yang akan ditimbulkan jika pengelolaan sampah tidak dilakukan secara baik.

Tabel 1 menunjukkan bahwa sebanyak 43,92\% responden memiliki tingkat kesadaran tinggi terhadap pengelolaan sampah, sedangkan $30,41 \%$ responden memiliki tingkat kesadaran rendah dan 25,68\% responden memiliki tingkat kesadaran cukup. Hal ini mengindikasikan bahwa rata-rata tingkat kesadaran responden terhadap pengelolaan sampah hanya $40 \%$ karena mereka masih memiliki alasan yang kuat untuk membuang sampah seenaknya yakni bahwa sudah menjadi kebiasaan bagi masyarakat setempat untuk membuang sampah ke tepi pantai, tidak ada aturan/larangan untuk membuang sampah ke tepi pantai, lebih mudah membuang sampah ke tepi pantai dan tidak tersedia tempat pembuangan sampah (TPS) yang representative.

\subsection{Faktor yang Mempengaruhi Kesadaran Masyarakat Pesisir Terhadap Sampah}

Kesadaran masyarakat pesisir terhadap sampah dipengaruhi oleh faktor pengetahuan, sikap, dan perilaku. Permasalahan tentang sampah meliputi tiga bagian mulai dari hilir, proses dan hulu. Pembuangan sampah terus mengalami peningkatan terjadi di hilir. Terdapat keterbatasan sumber daya baik masyarakat maupun pemerintah untuk menganangani sampah terjadi di bagian proses. Pemrosesan akhir belum diterapkan dengan sistem yang optimal terjadi di hulu (Mulasari et al, 2016). Kebanyakan masyarakat lebih senang membuang sampah ke sungai atau ke laut karena lebih mudah dan menjadi kebiasaan. Selain itu juga ada yang memilih membakar sampah karena menurut responden aktivitas tersebut merupakan bagian dari pengolahan sampah. Padahal pembakaran sampah menyebabkan pencemaran lingkungan dan mengganggu kesehatan. Sikap demikian terjadi karena dipengaruhi kematangan usia dan pengetahuan (Mulasari, 2012).

Peningkatan kesadaran masyarakat tidak mudah. Hal ini membutuhkan usaha dan kerja sama pihakpihak seperti pemerintah, masyarakat, dan swasta. Membutuhkan waktu lama untuk meningkatkan kesadaran masyarakat. Kebanyakan orang akan melihat bukti nyata dan contoh kongkrit dalam penangangan sampah. Semua pihak yang kompeten harus konsisten untuk mengelola sampah dan memotivasi masyarakat untuk mengelola persampahan (Rizal, 2011).

Analisis faktor yang mempengaruhi kesadaran masyarakat terhadap pengelolaan sampah dikaji dari pengetahuan, sikap dan perilaku. Terlihat bahwa pengetahuan dan sikap berpengaruh terhadap perilaku kemudian perilaku akan mempengaruhi kesadaran masyarakat terhadap pengelolaan sampah. Model analisis yang dipakai untuk menganalisis variabelvariabel tersebut digunakan analisis model SEM-PLS berbasis varians dilakukan untuk menilai outer model atau pengukuran model yang menghubungkan variabel manifes dengan variabel laten; menilai inner model, variabel laten terkait satu sama lain berdasarkan model diagram jalur. Hasil analisis ditampilkan pada Gambar 2 . 
Tabel 1. Gambaran Pengetahuan, Sikap, Perilaku dan Kesadaran Masyarakat Terhadap Sampah di Kota Ambon

\begin{tabular}{|c|c|c|c|c|}
\hline \multirow{2}{*}{ No. } & \multirow{2}{*}{ Uraian } & \multirow{2}{*}{ kategori } & \multicolumn{2}{|c|}{ Persentase Respons Masyarakat Terhadap Sampah } \\
\hline & & & Jumlah (orang) & Persentase \\
\hline \multirow[t]{3}{*}{1} & Pengetahuan & Baik & 85 & 57,43 \\
\hline & & Kurang Baik & 63 & 42,57 \\
\hline & & & 148 & 100 \\
\hline \multirow[t]{3}{*}{2} & Sikap & Baik & 82 & 55,41 \\
\hline & & Kurang Baik & 66 & 44,59 \\
\hline & & & 148 & 100 \\
\hline \multirow[t]{3}{*}{3} & Perilaku & Baik & 90 & 60,81 \\
\hline & & Kurang Baik & 58 & 39,19 \\
\hline & & & 148 & 100 \\
\hline \multirow[t]{4}{*}{4} & Kesadaran & Tinggi & 65 & 43,92 \\
\hline & & Sedang & 38 & 25,68 \\
\hline & & Rendah & 45 & 30,41 \\
\hline & \multicolumn{2}{|c|}{ Jumlah } & 148 & 100 \\
\hline
\end{tabular}

Sumber data primer diolah, 2021

Tabel 2. Nilai Konstruk Reliabilitas dan Validitas

\begin{tabular}{lcccc}
\hline & Cronbach's Alpha & rho_A & Reliabilitas Komposit & $\begin{array}{c}\text { Rata-rata Varians Diekstrak } \\
\text { (AVE) }\end{array}$ \\
\hline Kesadaran & 0,841 & 0,881 & 0,903 & 0,757 \\
Pengetahuan & 0,737 & 0,740 & 0,849 & 0,653 \\
Perilaku & 0,766 & 0,852 & 0,863 & 0,682 \\
Sikap & 0,770 & 0,918 & 0,851 & 0,657 \\
\hline
\end{tabular}

Sumber data primer diolah, 2021

Tabel 3. Nilai Kriteria Fornell-Larcker

\begin{tabular}{|c|c|c|c|c|}
\hline & Kesadaran & Pengetahuan & Perilaku & Sikap \\
\hline Kesadaran & 0,870 & & & \\
\hline Pengetahuan & 0,577 & 0,808 & & \\
\hline Perilaku & 0,485 & 0,452 & 0,826 & \\
\hline Sikap & 0,843 & 0,478 & 0,826 & 0,811 \\
\hline
\end{tabular}

Sumber data primer diolah, 2021

Tabel 4. Nilai Path coefficient hasil bootstrapping

\begin{tabular}{lrrrrr}
\hline Konstruk & $\begin{array}{c}\text { Sampel Asli } \\
\text { (O) }\end{array}$ & $\begin{array}{c}\text { Rata-rata Sampel } \\
\text { (M) }\end{array}$ & $\begin{array}{c}\text { Standar } \\
\text { Deviasi } \\
\text { (STDEV) }\end{array}$ & $\begin{array}{c}\text { T Statistik } \\
\text { (O/STDEV) }\end{array}$ & P Values \\
\hline Pengetahuan -> Perilaku & 0,075 & 0,117 & 0,158 & 0,472 & 0,637 \\
Perilaku -> Kesadaran & 0,485 & 0,506 & 0,133 & 3,647 & 0,000 \\
Sikap -> Perilaku & 0,790 & 0,778 & 0,126 & 6,290 & 0,000 \\
\hline Sumber data primer diolah, 2021 & & & & &
\end{tabular}

Sumber data primer diolah, 2021

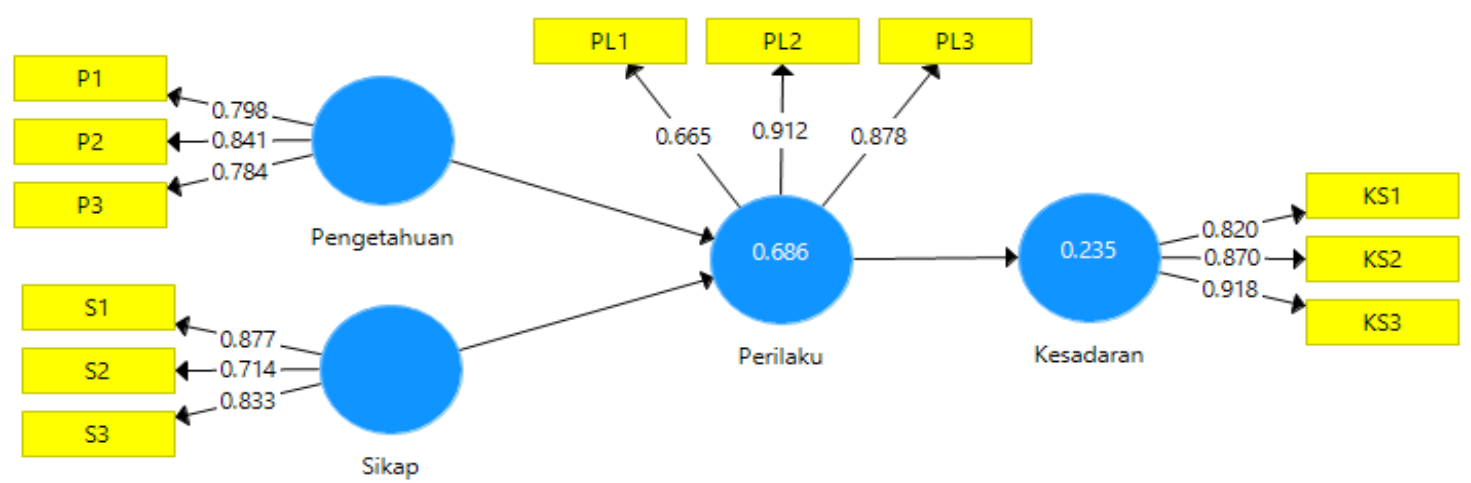

Gambar 2. Nilai loading factor (outer path), path coefficients (inner path), dan R squares sebagai nilai baku pada model 


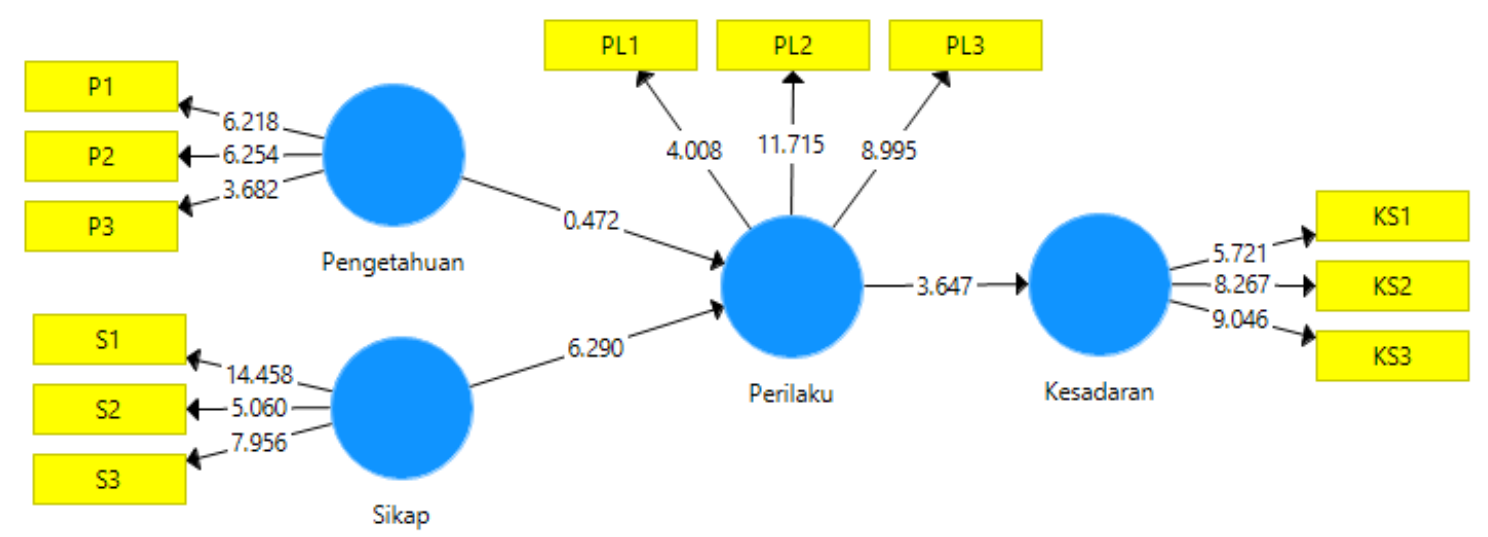

Gambar 3. Nilai t-Value hasil bootstrapping antar konstruk (Inner model)

Model pengukuran menggunakan reliabilitas dengan nilai Cronbach's Alpha untuk nilai minimum adalah 0,7. Nilai c (compositereliability) diinterpretasikan sama dengan Cronbach's Alpha. Composite reliability mengukur nilai sesunggunya reliabilitas suatu konstruk. Varian indicator harus dapat dijelaskan oleh variabel laten minimal 50\%. Nilai korelasi absolut antar variabel laten dan indikator lebih besar dari 0,7 .

Pendekatan kedua untuk menilai validitas diskiminan adalah Nilai kriteria Fornell-Larcker. Nilai ini untuk membandingkan square root dari nilai AVE dengan korelasi variable laten. Nilai square root untuk tiap konstruk AVE lebih besar dari korelasi tertinggi dengan konstruk lainnya. Tabel 3 menampilkan Nilai kriteria Fornell-Larcker. Nilai validitas diskriminan dengan nilai AVE ditampilkan pada tabel 2. Terlihat bahwa nilainya lebih besar dari 0,5. Konsistensi internal berdasarkan nilai composite reliability memperoleh nilai lebih besar 0,6. Uji pengukuran measurment model antar konstruk (kesadaran, pengetahuan, perilaku dan sikap) untuk setiap indikator memenuhi standar, korelasi antar konstruk dengan indikator bisa digunakan dalam model.

Uji goodness-fit-model untuk pengujian model struktural memperlihatkan nilai R-Square untuk konstruk kesadaran dan perilaku yaitu 0,235 dan 0,686 yang berarti setiap peningkatan sikap dapat memberikan pengaruh terhadap kesadaran dan perilaku sebesar $23,5 \%$ dan $68,6 \%$. Sedangkan sisanya dipengaruhi oleh faktor lain yang tidak ada di dalam model yaitu masing-masing sebesar 76,5\% dan 31,4\%.

Selanjutnya untuk menilai tingkat signifikansi atau probabilitas dari direct effects, indirect effects dan total effects menggunakan Bootstrapping. Melalui bootstrapping dapat menilai tingkat signifikansi nilainilai lainnya seperti $r$ square dan adjusted $r$ square, $f$ square, outer loading dan outer weight. Hasil bootsrapping ditampilkan pada Gambar 3.

Konstruk pengetahuan tidak berpengaruh signifikan terhadap konstruk perilaku dengan nilai tnya ( $\mathrm{t}$ Pengetahuan -> Perilaku $=0,472$ lebih kecil dari nilai yang disarankan ( $\mathrm{t}$-value $<1,96)$. Untuk konstruk perilaku berpengaruh signifikan terhadap konstruk kesadaran dengan nilai t-nya $>1,96 \quad(\mathrm{t}$ perilaku $\rightarrow$ kesadaran $=3,647$ ). Sementara itu, konstruk sikap memberikan pengaruh yang signifikan terhadap konstruk perilaku, nilai $\mathrm{t}$-nya $(\mathrm{t}$ sikap $\rightarrow$ perilaku= 6,290 ) lebih besar dari nilai $t$ yang disarankan $(t>$ 1,96). Hasil analissi tiap konstruk ditampilkan pada Tabel 4.

Pengetahuan tidak berpengaruh terhadap perilaku, hal ini disebabkan bahwa belum tentu seseorang mengetahui pengelolaan sampah kemudian secara langsung akan merubah perilaku. Aspek pengetahuan yang terdiri dari mengetahui, memahami dan mengaplikasikan sangat membutuhkan waktu yang lama untuk masyarakat Kota Ambon tanggap terhadap pengelolaan sampah.

Perilaku masyarakat terhadap sampah sudah membudaya dan mengakar. Pola pikir masyarakat terhadap sampah harus dirubah agar sampah dapat tertangani dengan baik. Kebanyakan sampah masyarakat menumpuk di tengah laut, di tepi pantai bahkan di dasar laut. Hal ini membuat laut tidak bersih, tercemar, lingkungan sekitar menjadi kotor dan tidak sehat. Perilaku berpengaruh terhadap kesadaran karena beberapa unsur perilaku yang diteliti yaitu kebiasaan, keyakinan dan prinsip. Masyarakat yang membuang sampah ke tepi pantai/laut merupakan kebiasaan maka sulit untuk berubah, namun jika kebiasaan seseorang menaruh sampah pada tempat yang disediakan pemerintah maka masalah sampah dapat tertangani dengan baik. Keyakinan yang teguh untuk mengatasi sampah, menjadi tanggung jawab bersama maka masalah sampah akan teratasi. Prinsip yang kokoh untuk mengatasi sampah supaya lingkungan tempat tinggal, lingkungan pesisir, lingkungan laut menjadi bersih sehingga enak dipandang mata. Perilaku baik maka akan selalu muncul kesadaran akan pentingnya menjaga lingkungan supaya bersih dan sehat. Masyarakat sangat mengharapkan adanya campur tangan pemerintah dalam mengatasi sampah. Keinginan masyarakat supaya pemerintah membuat bak penampung sampah yang besar, diletakan pada 
tempat-tempat yang representative, dapat dijangkau masyarakat dan mereka akan membayar retribusi sampah. Penelitian ini didukung oleh Mulasari et al, 2016 bahwa harapan masyarakat supaya pengelolaan sampah ditangani oleh pemerintah. Masyarakat akan membayar retribusi kebersihan dibandingkan harus mencari lokasi pembuangan sampah atau mengambil jalan pintas untuk membuang sampah di laut. Hal ini didukung oleh penelitian Dilla, 2007 bahwa masyarakat sangat berharap pemerintah bertanggungjawab terhadap pengelolaan sampah domestik. Kemudian masyarakat diwajibkan untuk membayar retribusi kebersihan.

Menurut Sahil (2016) bahwa penanganan sampah melibatkan beberapa aspek seperti bak sampah, pemindahan, pengangkutan, pengumpulan dan pengolahan serta tempat pembuangan akhir (Sahil, 2016). Selain itu responden selalu mengatakan bahwa tidak ada perencanaan pemerintah untuk mengolah sampah secara kontinu. Hasil penelitian Nilam (2016) mengatakan bahwa belum adanya tempat pengolahan sampah akan menjadi persoalan besar. Karena tidak semua lapisan masyarakat sadar akan sampah.

\subsection{Kebijakan dan Aturan Tentang Pengelolaan Sampah}

Sikap dan perilaku masyarakat yang peduli sampah maka akan timbul kesadaran akan pentingnya mengelola sampah. Pengetahuan tidak memberikan pengaruh terhadap perilaku seseorang untuk peduli sampah. Sikap mempengaruhi perilaku dan akan berdampak pada kesadaran akan pentingnya mengelola sampah secara baik. Jumlah penduduk yang semakin bertambah dibarengi dengan pola konsumsi yang berubah secara tidak langsung akan meningkatkan jenis, karakteristik dan volume sampah yang beragam.

Perlu adanya penanganan sampah secara komprehensif dan terpadu karena sampah bukan hanya menjadi masalah lokal dan daerah tetapi sudah menjadi masalah nasional. Jika pengolahan sampah dilakukan secara baik maka akan berdampak secara ekonomi, kehidupan masyarakat akan lebih sehat, aman untuk lingkungan dan perilaku masyarakat akan mengalami perubahan. Hal ini sesuai dengan Undang Undang Dasar Negara Republik Indonesia Tahun 1945 pasal $28 \mathrm{H}$ ayat (1). Sampah merupakan barang yang tidak diinginkan, sebagai sisa buangan masyarakat setiap hari baik padat maupun tidak padat, organik maupun anorganik, terurai atau tidak terurai yang dibuang ke lingkungan. Jumlah sampah yang semakin meningkat tidak diimbangi dengan proses pengolahan merupakan sumber pengrusakan dan pencemaran bagi lingkungan secara global. Secara spesifik sampah di atur dengan undang-undang maupun peraturan antara lain: UU RI Nomor 18 Tahun 2008 dan Peraturan Pemerintah RI Nomor 81 Tahun 2012, Undang-undang Nomor 18 Tahun 2018, Undang-undang Nomor 32 Tahun 2009, Peraturan Pemerintah Nomor 27 Tahun 2020, Peraturan Menteri Lingkungan Hidup dan 372
Kehutanan Nomor 14 Tahun 2021, Peraturan Menteri Lingkungan Hidup dan Kehutanan Nomor 70 Tahun 2016, Perpres No. 97 Tahun 2017.

Undang-undang dan peraturan yang mengatur sampah harus disosialisasikan secara kontinu kepada masyarakat, agar pengetahuan masyarakat tentang sampah semakin bertambah, perilaku dan sikap masyarakat untuk tanggap terhadap pengelolaan sampah dan menimbulkan kesadaran yang tinggi terhadap sampah. Hasil penelitian menunjukkan bahwa tanggapan renspoden terhadap pelanggaran aturan hukum yang berlaku tentang sampah. Tanggapan responden ditampilkan pada Gambar 4.

Gambar 4 memperlihatkan bahwa $72,7 \%$ responden menanggapi bahwa membuang sampah sembarangan sangat melanggar aturan. Kemudian $23,8 \%$ memberi tanggapan bahwa membuang sampah sembarangan tidak melanggar aturan. Selain itu terdapat 3,5\% menyatakan bahwa tidak ada aturan yang mengikat tentang membuang sampah sembarangan. Terlihat bahwa responden tanggap terhadap sampah sebanyak 72,7\% karena ada informasi berupa baliho atau papan iklan yang mengkampanyekan untuk tidak membuang sampah sembarangan. Namun terlihat bahwa sosialisasi aturan dan kebijakan tentang sampah tidak kontinu disuarakan kepada seluruh masyarakat.

Selain itu menurut tanggapan reeponden terdapat sanksi jika masyarakat membuang sampah sembarangan ditampilkan pada Gambar 5. Respons masyarakat terhadap pembuangan sampah terlihat bahwa masyarakat diberikan sanksi sebanyak 62,2\% berupa teguran secara lisan, peringatan tertulis, dan pembayaran denda berupa uang kebersihan lingkungan. Sedangkan 37,8\% responden menyatakan bahwa tidak ada sanksi, sehingga mereka membuang sampah seenaknya saja tanpa adanya kepedulian tentang kebersihan lingkungan.

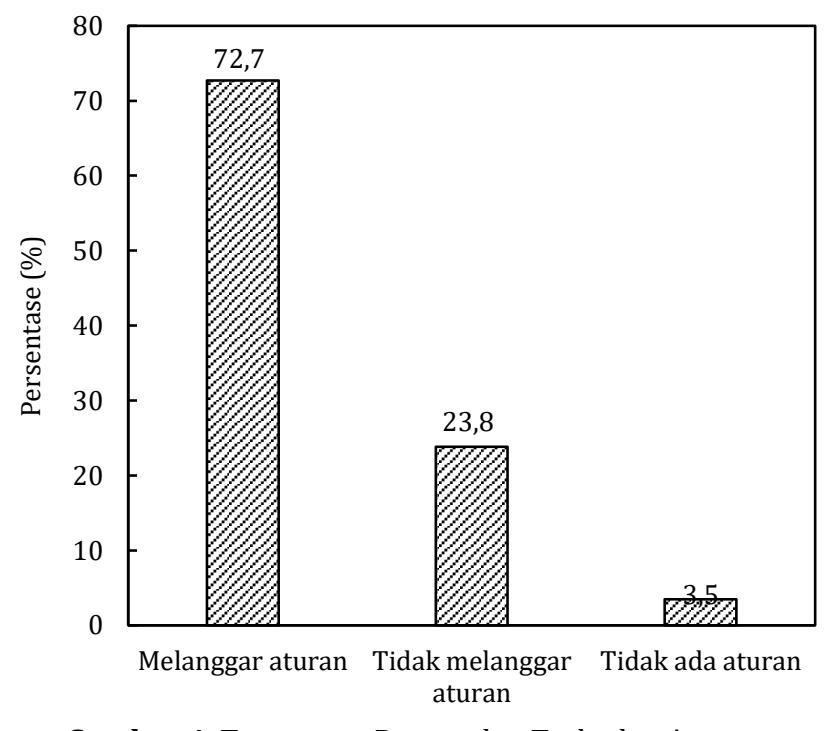

Gambar 4. Tanggapan Responden Terhadap Aturan Tentang Sampah 


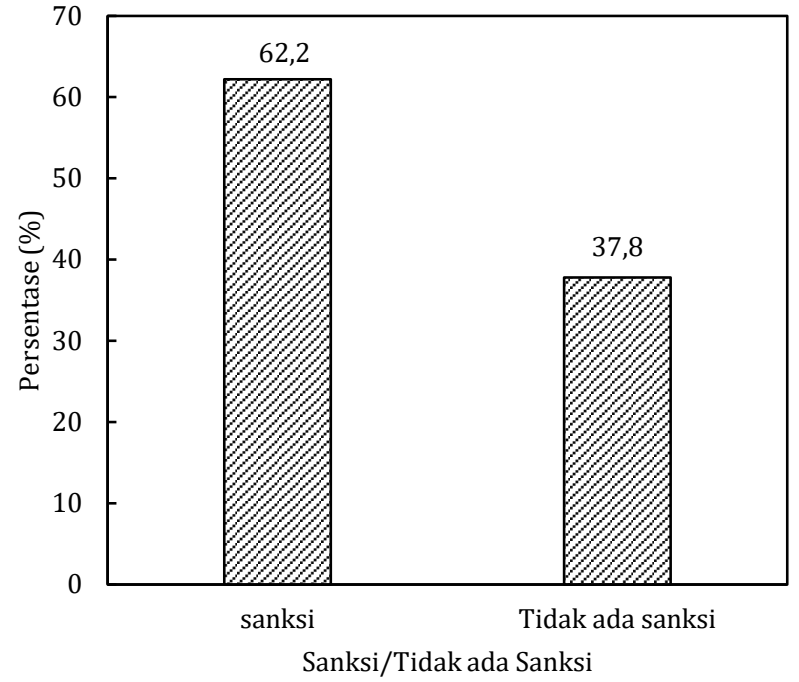

Gambar 5. Tanggapan Responden Terhadap Sanksi Pembuangan Sampah

Berdasarkan Gambar 4 dan Gambar 5 terlihat bahwa pemerintah harus terus menyuarakan kepada masyarakat tentang kesadaran mengelola sampah secara terpadu dan komprehensif sehingga masalah sampah tidak semakin besar. Pemerintah harus mensosialisasikan aturan dan kebijakan sampah kepada seluruh lapisan masyarakat supaya tidak membuang sampah di hulu karena akan berdampak di hilir yakni laut akan menerima berton-ton sampah masyarakat yang dibuang seenaknya tanpa kepedulian yang tinggi untuk menjaga lingkungan secara berkelanjutan. Hasil ini didukung oleh penelitian Titaley et al, 2020 bahwa minimnya fasilitas menyebabkan penumpukan sampah semakin meningkat dan menyebabkan masyarakat di pulaupulau kecil tidak punya pilihan selain membuang sampah ke laut atau membuangnya ke tempat terbuka.

\section{Kesimpulan}

Model struktural berdasarkan nilai t-value, menunjukkan bahwa konstruk pengetahuan tidak memberikan pengaruh yang signifikan terhadap konstruk perilaku, karena nilai t-nya (t Pengetahuan -> Perilaku =0,472 lebih kecil dari nilai yang disarankan (t-value< 1,96). Pada konstruk perilaku memberikan pengaruh yang signifikan terhadap konstruk kesadaran, nilai t-nya $>1,96 \quad$ (t perilaku $\rightarrow$ kesadaran=3,647). Sementara itu, konstruk sikap memberikan pengaruh yang signifikan terhadap konstruk perilaku, nilai $\mathrm{t}$-nya $(\mathrm{t}$ sikap $\rightarrow$ perilaku $=$ $6,290)$ lebih besar dari nilai $t$ yang disarankan $(\mathrm{t}>$ 1,96).

Nilai R-Square yang merupakan uji goodness-fitmodel. Berdasarkan nilai R-Square, diperoleh nilai untuk konstruk kesadaran dan perilaku masingmasing sebesar 0,235 dan 0,686. Hal ini dapat dijelaskan bahwa untuk setiap peningkatan sikap dapat memberikan pengaruh terhadap kesadaran dan perilaku masing-masing sebesar 23,5\% dan 68,6\%. Sedangkan sisanya yaitu masing-masing sebesar 76,5\% dan 31,4\% dipengaruhi oleh faktor lain di luar model yaitu aturan dan kebijakan sampah meliputi UU RI Nomor 18 Tahun 2008 dan Peraturan Pemerintah RI Nomor 81 Tahun 2012, Undang-undang Nomor 18 Tahun 2018, Undang-undang Nomor 32 Tahun 2009, Peraturan Menteri Lingkungan Hidup dan Kehutanan Nomor 70 Tahun 2016, Perpres No. 97 Tahun 2017, Peraturan Pemerintah Nomor 27 Tahun 2020.

\section{DAFTAR PUSTAKA}

Ahmadi, A. 2009. Psikologi Sosial (Jakarta: Rineka Cipta), p. 150.

Andi, N, A. 2021. LIPI: Kepadatan Sampah Plastik di Teluk Ambon Terus Naik https://www.republika.co.id/berita/qv24fm384/lipikepadatan-sampah-plastik-di-teluk-ambon-terus-naik

Azwar, S. 2015. Sikap Manusia Teori Dan Pengukurannya (Yogyakarta: Pustaka Pelajar) p. 5.

Banga, M. 2008. "The Economics of Solid Waste Management. The Case of Kampala City, Uganda." PhD Thesis. Dar-es-Salaam University.

Banga, M. 2011. Household Knowledge, Attitudes and Practices in Solid Waste Segregation and Recycling: The Case of Urban Kampala. Zambia Social Science Journal, 2(1): 27-39.

Dilla, M., Natsir, M.T., Onesinus. 2007. Baseline Service of Community and Cleaning Agency orf Municipal Solid Waste Management in Makasar of South Sulawesi. Journal of Applied Sciences in Enveronmental Sanitation, 2 (2): 63-66.

Elamin, M. Z., Ilmi, K. N., Tahrirah, T., Zarnuzi, Y. A., Suci, Y. C., Rahmawati, D. R., Kusumawardhani, R., Dwi, D. M., Rohmawati, R. A., Bhagaskoro, P. A., Nasifa, I. F. 2018. Analisis Pengelolaan Sampah Pada Masyarakat Desa Disanah Kecamatan Sreseh Kabupaten Sampang. Jurnal Kesehatan Lingkungan, 10(4): 368-375.

Ekere, W. J. Mugisha; and L. Drake. 2009. “Factors Influencing Waste Separation and Utilization among Households in the Lake Victoria Crescent, Uganda." Waste Management 29: 3047-3051.

Hardiatmi, S. (2011) Pendukung Keberhasilan Pengelolaan Sampah Kota. INNOFARM. Jurnal Inovasi Pertanian, 10 (1): 50-66.

Mar'at. 1984. Sikap Manusia Perubahan serta Pengukurannya (Jakarta: Ghalia Indonesia) p. 10.

Marojahan, R. 2015. Hubungan Pengetahuan Masyarakat Tentang Sampah Dengan Perilaku Mengelola Sampah Rumah Tangga Di Rt 02 Dan Rt 03 Kampung Garapan Desa Tanjung Pasir Kecamatan Teluk Naga Kabupaten Tangerang. Forum Ilmiah 12(1).

Mulasari, A., Heru, H. A., dan Muhadjir N. 2016. Analisis Situasi Permasalahan Sampah Kota Yogyakarta dan Kebijakan Penanggulangannya. Jurnal Kesehatan Masyarakat, 11(2):96-106.

Mulasari, S. A. 2012. Hubungan tingkat pengetahuan dan sikap terhadap perilaku masyarakat dalam mengelola sampah di dusun padukuhan desa sidokarto kecamatan 
godean kabupaten sleman yogyakarta. Jurnal Kesmas, 6(3): 204-211.

Muttaqien, K., Sugiarto, Sarifudin, S. 2019. Upaya Meningkatkan Kesadaran Masyarakat Terhadap Kesehatan Lingkungan Melalui Program Bank Sampah. Studi Deskriptif Pada Masyarakat RW 09 Kelurahan Cipadung Kidul Kecamatan Panyileukan Kota Bandung. Indonesian Journal of Adult and Community Education, 1(1): 6-11

Nilam, S.P. 2016. Analisis Pengelolaan Sampah Padat di Kecamatan Banuhampu Kabupaten Agam. Jurnal Kesehatan Masyarakat Andalas, 10(2): 157-165.

Notoatmodjo, S. 2007. Promosi Kesehatan dan Ilmu Perilaku. Jakarta: Rineka Cipta.

Notoatmodjo, S. 2005. Metodologi Penelitian Kesehatan. Jakarta: Rineka Cipta.

Omran, A. A.; Mahmood; H. Abdul Aziz; and G. M. Robinson. 2009. "Investigating Households' Attitude towards Recycling of Solid Waste in Malaysia: A case study." International Journal of Environmental Research 3, no 2: $275-288$

Pelasula, D. 2021. Sampah Makin Tak Terkendali di Perairan Teluk Ambon, Ini 8 Wilayah Sumber Sampah https://beritabeta.com/sampah-makin-tak-terkendalidi-perairan-teluk-ambon-ini-8-wilayah-sumbersampah/all
Pokhrel, D. and T. Viraraghavan. 2005. "Municipal Solid Waste Management in Nepal: Practices and Challenges." Waste Management 25: 555562.

Rizal, M. 2011. Analisis Pengelolaan Persampahan Perkotaan (Studi kasus pada kelurahan Boya Kecamatan Banawa Kabupaten Donggala). Jurnal Sipil Mesin Arsitektur Elektro (SMARTek), 9(2): 155-172.

Sahil, J., Muhdar, M. H. I. Al., Rohman, F., Syamsuri, I. 2016. Sistem Pengelolaan dan Upaya Penanggulangan Sampah di Kelurahan Dufa-Dufa Kota Ternate. Jurnal Bioedukasi, 4(2): 478-487.

Slamet, R. A. L. 2016. Ilmu Kesehatan Masyarakat Yogyakarta: Andi.

Sohilait, I. 2019. Kota Ambon Produksi Sampah 162,5 Ton Per Hari. https://kumparan.com/lenteramaluku/kotaambon-produksi-sampah-162-5-ton-per-hari

Titaley, S., Timisela, N.R., Titaley, J. 2020. Assessment of Waste Management on Small Island. Journal of Advanced Research in Dynamical \& Control Systems, 12(2): 984-993.

Toisuta, C., dan Salampessy, Z. 2019. Sampah Menggunung di Dasar Teluk Ambon. https://www.gatra.com/detail/news/444258/milenia l/sampah-menggunung-di-dasar-teluk-ambon. 